\title{
A Roadmap for Cost of Goods Planning to Guide Economic Production of Cell Therapy Products
}

Running Title: A Roadmap for COG Planning in Cell Therapy

Yonatan Y Lipsitz ${ }^{1}$, William D Milligan ${ }^{2}$, Ian Fitzpatrick ${ }^{3}$, Evelien Stalmeijer ${ }^{4}$, Suzanne S Farid $^{5}$, Kah Yong Tan ${ }^{6}$, David Smith ${ }^{7}$, Robert Perry ${ }^{8}$, Jessica Carmen ${ }^{9}$, Allen Chen ${ }^{10}$, Charles Mooney ${ }^{11}$, John Fink ${ }^{12}$

All belonging to the ISCT Business Models and Cost of Goods Subcommittee of the ISCT Commercialization Committee

Corresponding Author: yonatan.lipsitz@mail.utoronto.ca

\footnotetext{
${ }^{1}$ Institute for Biomaterials and Biomedical Engineering, University of Toronto, Toronto, Canada

${ }^{2}$ Steminent Biotherapeutics, Taipei, Taiwan

${ }^{3}$ Scinogy Pty Ltd, Melbourne, Australia.

${ }^{4}$ eXmoor Pharma Concepts, Berkshire, UK

${ }^{5}$ University College London, London, UK.

${ }^{6}$ Bioprocessing Technology Institute, A*STAR, Singapore.

${ }^{7}$ PCT, a Caladrius Company, Allendale, USA

${ }^{8}$ Atara Biotherapeutics, San Francisco, USA

${ }^{9}$ MaxCyte, Gaithersburg, USA

${ }^{10}$ Bioprocessing Technology Institute, A*STAR, Singapore.

${ }^{11}$ Oklahoma Blood Institute, Oklahoma City, USA.

${ }^{12}$ Brooks Automation, Chelmsford, USA.
} 


\title{
ABSTRACT
}

Cell therapy products are frequently developed and produced without incorporating cost considerations into process development, contributing to prohibitively costly products. Herein we contextualize individual process development decisions within a broad framework for cost efficient therapeutic manufacturing. This roadmap guides the analysis of Cost of Goods (COG) arising from tissue procurement, material acquisition, facility operation, production, and storage. We present the specific COG considerations related to each of these elements as identified through a 2013 International Society for Cellular Therapy (ISCT) COG survey, highlighting the differences between autologous and allogeneic products. Planning and accounting for COG at each step in the production process could reduce costs, allowing for more affordable market pricing to improve the long term viability of the cell therapy product and facilitate broader patient access to novel and transformative cell therapies.

\section{KEYWORDS}

Cell therapy; Cost of Goods; COG; cellular development; autologous cell products; allogeneic cell products; tissue procurement; material costs; facility costs; production costs; storage; ISCT COG survey;

\author{
ABBREVIATIONS \\ COG: cost of goods \\ CMO: clinical manufacturing organization \\ hMSCs: human mesenchymal stem cells \\ FBS: fetal bovine serum \\ MM: minimally manipulated
}




\section{INTRODUCTION}

Current and expected pricing for approved and late-stage cellular therapy products reflect the high Cost of Goods (COG) used today to produce most therapies (Fig. 1). Optimizing COG will promote the development and commercialization of more affordable cell therapy products, which in turn are more likely to achieve reimbursement from payers and gain broader adoption for patient treatment ${ }^{1}$. Ideally, the economic aspects of a product will be addressed from the very beginning of development to enable a viable, profitable product lifecycle since process changes become more difficult as development progresses. A robust cell therapy business model cannot be fully realized without addressing every cost-relevant "needle-to-needle" consideration. Starting from cell sourcing through to manufacturing, distribution, and finally clinical application, COG optimization aims to minimize the cost per unit of cells and ultimately the cost per dose while maintaining product quality.

In June 2013, a survey was distributed to the ISCT membership asking about the COG breakdown in therapies under development by member organizations (See Fig S1 for survey overview). The survey results indicated that commonalities can be drawn between process components of similar cell products. The two main cell therapy modalities, allogeneic (donor to patient) and autologous (patient to self) necessitate different "needle-to-needle" pathways (Fig. 2). The production process differences between manufacturing strategies used for allogeneic products and the patient-specific manufacturing strategies used for autologous

products result in distinct COG optimization decisions. Notably, allogeneic products benefit highly from economies of scale in a similar manner to traditional pharmaceuticals, whereas costs are relatively consistent as autologous products are scaled out. 
In this paper, we outline a COG roadmap of key considerations and objectives for each step in cell manufacturing to plan for reduced COG, enable lower product pricing, and improve patient access. Designed to inform early process development of the connection between each development decision and the eventual cost-efficiency of the final therapy, this roadmap augments the ISCT COG survey results with relevant published references on how to address the challenges encountered with each manufacturing step (Fig. 3).

\section{COG Impact Analysis for Cell Therapy Products}

When beginning translation of a preclinical process to clinical production, the various manufacturing methods available can significantly impact the final COG at commercial scale. Impact analysis is a valuable tool to understand the sensitivity of the final COG in response to different manufacturing strategies and product demand scenarios forecast at the end of the

expected decade of development of a cell therapy ${ }^{2-5}$. By comparing future manufacturing scenarios to the current manufacturing process, this analysis will identify elements of both manufacturing strategy and development to prioritise for COG reduction. Common development priorities can include development of new technologies, distribution systems, shelf life enhancement, and closed system solutions and automation. Manufacturing strategy priorities often include CMO usage, number of manufacturing sites, central or decentralized manufacturing, and intermediate demand transition facility usage. Importantly, a quantitative understanding of the influence of process changes on the key factors that ensure product quality using frameworks such as Quality by Design should guide the decision to incorporate these COG reduction steps (described by Lipsitz et al ${ }^{6}$ ). 
Analysis of the COG roadmap early in development can help determine the impact of different scenarios on achieving a future cost-optimal process. These scenarios should consider variations such as differences in future demand, process automation, shorter versus longer shelf life of final product, and point of care needs. Comparison of different scenarios will show which considerations have the highest impact on the overall COG and on quality risk, specific for each cell product. To analyze manufacturing COG, processes and outcomes for each manufacturing step should be carefully described. These steps include tissue procurement, material acquisition, facility operation, production, and storage (Table 1). As clinical development progresses, the model predicting the impact of these decisions on final COG can be updated for relevance and accuracy. The following sections provide insights from the ISCT COG survey and relevant literature into the cost considerations associated with each of these steps.

\section{Tissue Procurement}

Tissue stability during transport from the site of origin to processing can have high COG consequences. In many cases, cadaveric tissue must be processed when it becomes available, requiring a processing facility to operate continuously. Fresh material drawn from clinical sites will be shipped Monday to Friday. Patient procedures such as apheresis or bone marrow recoveries are preferred by the patients to be late in the week, allowing them the weekend to recover before work. These concerns affect COG through facility utilization and labor demand profiles, and the supply chain logistic must be optimized to minimize this impact.

Tissue procurement considerations differs greatly between allogeneic and autologous therapies (highlighted in Table 2). In allogeneic therapies, cells for routine manufacturing are sourced 
from specially recruited donors. The cost to recruit and incentivize each donation is directly related to the size of the qualifying donor pool. Donors must be willing and able to undergo stringent screening procedures to protect both the donor and the product recipient. Additionally, it is critical that tissue and donor screening adheres to regulatory agency donor and procurement guidelines for all markets where the cells may be ultimately used. Failure to do so can result in therapies unsuitable for use in certain markets. As well, one must determine the need for and frequency of primary cell culture qualification, which poses a significant cost on production.

In autologous therapies, consistent acquisition processes for multiple patients at multiple clinics must be established and controlled, since common techniques such as bone marrow acquisition and apheresis can be highly operator dependent ${ }^{7-10}$. Variability in acquisition is compounded by variability in donor samples ${ }^{11-13}$, both of which must be understood in a manufacturing context to ensure consistent cell therapy product quality. Notably, development is often conducted on healthy samples, without indication of how diseased samples will perform until phase I trials, introducing manufacturing risk that may impact timelines and development costs. The regulatory requirements of ensuring GMP compliant, sterile procurement, handling, preservation, and storage of the starting materials also add significant costs to tissue acquisition. In certain cases, the drugs required to procure the desired tissue (e.g. mobilisation of stem cells to peripheral blood) may represent an important cost consideration. 


\section{Material Acquisition}

Overall, forty percent of ISCT COG survey participants estimated that greater than 20\% of their COG are due to media (12\% of respondents estimated the COG to be between $20-30 \%$; 24\% estimated between 30-50\%; and 4\% estimated a COG greater than 50\%). On average, the estimated materials costs accounted for 36\% of overall manufacturing COG. In addition, 92\% of survey participants have considered using serum-free or xeno-free media, however, greater than $50 \%$ of participants did not understand the cost-impact of switching to serum-free or xeno-free media.

Cell growth media components can be divided into two functions: maintaining basic functions required for cell survival and maintaining advanced functions required for cell state and differentiation. Basal media which allow for cell survival and growth are well established, and the growth factors, cytokines, and signaling molecules required for cell state and differentiation account for the major media costs. While many cells (notably hMSCs) have been generated through conventional static adherent cultures in the presence of fetal bovine serum (FBS) for

clinical applications ${ }^{14}$, these methods are not appropriate to meet the expected future demand for safe, quality-assured hMSCs for global human therapeutic use. FBS is a complex and undefined mixture of proteins, signaling molecules, and other bioactive factors that vary in concentration and activity between batches. Furthermore, a significant supply chain challenge exists for sourcing sufficient FBS to meet demand as these products approach commercial scale production. Sustainability of the supply chain can often be a critical risk and cost driver. Single-use disposables incur a significant cost per patient in patient specific therapies. For example, CD34 microbeads and a single-use cell sorting tube-set for hematopoietic therapies 
can cost $>\$ 7000$ simply to purify the starting cells for further processing (See Table 3 for more examples).

\section{Facility Operation and Labor}

Of ISCT COG survey respondents, 94\% used fresh starting material and planned to deliver fresh product, which can be challenging to manufacture due to stability and contamination issues. 68\% of respondents planned to manufacture internally in their own facility, though 33\% of respondents did not know what this would cost.

Facility costs are strongly affected by the choice between a "fresh" (non-cryopreserved) product and a cryopreserved product amenable to longer storage and transport times. A fresh product component restricts a facility's market reach and ties manufacturing to the patient and clinic schedules, possibly necessitating a multicenter approach. In contrast, cryopreserved products can be manufactured at a single centralized site which meets the regulatory requirements in each primary market to be considered (Table 4).

This choice between centralized and multicenter manufacturing impacts several cost considerations, such as the logistics of future capacity increases and the potential hurdle of technology transfer from one facility to another ${ }^{15,16}$ (Table 4). This choice can be made by first determining the demand forecast for the marketed product, which dictates the scale of manufacturing required. This informs whether manufacturing will be outsourced to a contract manufacturing organization (CMO), done internally, or divided between the two options. Importantly, if multiple sites will be required, analytical tools will be needed to ensure comparability in manufactured product between sites. 
In addition to distinguishing between fresh and frozen products, the level of cell manipulation influences facility costs. Autologous, minimally-manipulated products do not require costly GMP processing, while more-than minimally-manipulated products would incur these costs ${ }^{17}$. Allogeneic therapies are all manipulated cell products where facility costs can be reduced on per unit basis as the process is scaled up. Strategies for cost-effective progressive batch-size increases should be implemented when moving towards commercial production scales.

Labor is a dominant cost factor: $47 \%$ of ISCT COG survey respondents reported $>30 \%$ of COG were due to labor costs with processes comprising between 2 to 15 steps. Respondents indicated the need for automated processing to increase productivity and reduce labor costs. Allogeneic products benefit from the ability to share labor costs in a batch across many patient doses. Autologous therapies often include complex manipulations requiring skilled labor and long production times, increasing cost per dose. Increasing demand for autologous products can only be met by increasing the number of batches. Autologous products with a large manual component can also struggle with scale-out from the lack of access to skilled labor either due to geographic issues or, when establishing new manufacturing sites, due to disruption of the core manufacturing team to enable technology transfer. Thus, automation of autologous processes has emerged as a tactic to alleviate the high COG associated with manual methods requiring a skilled workforce.

A related key cost driver is the development of functionally closed systems. By closing manufacturing systems, non-classified spaces can be used instead of more costly class 10000 (Grade C, / ISO 7) facilities. Gowning and training costs are also reduced (See Fig. 4), and 
decentralized manufacturing systems can more readily be incorporated (Table 4). Key considerations for labor costs are outlined in Table 5

\section{Production: Scaling Up Cell Expansion}

$60 \%$ of respondents planned to use fewer than $3 * 10^{6}$ cells per $\mathrm{kg}$ dose. $64 \%$ planned to launch with fewer than 50000 doses per year as their commercial target, and 43\% planned launch with fewer than 10000 doses per year as their commercial target. 38\% of the ISCT COG survey respondents indicated that cell processing is the rate-limiting factor in manufacturing, contributing substantially to manufacturing costs.

To provide commercial quantities of allogeneic, clinical-grade cell therapy products as well as many patient-specific, expansion-dependent therapy products,, an efficient cell expansion method that reliably produces high quality at acceptable cost is required ${ }^{18}$. Trade-offs will occur between the cost of developing process knowledge to ensure product quality in manufacturing and scale-up versus the costs of discarding batches that do not meet specifications. Quality by Design is a risk-based framework that can guide cell therapy process development and scale-up to identify and control the properties most likely to influence product safety and efficacy ${ }^{6}$. By overlaying a quantitative understanding of how process parameters affect cell quality with the costs of gaining that knowledge and the costs associated with not having this knowledge, Quality by Design process development closely complements COG reduction strategies.

Key considerations for technology selection when scaling up cell expansion are highlighted in Table 6. The anticipated demand for large numbers of cells will necessitate bioreactor production methods, an alternative to traditional planar culture. Different bioreactor types and scales can be tailored to different operating sizes and target doses ${ }^{19}$. Simaria et al. ${ }^{3}$ present a 
detailed process economics analysis for allogeneic cell expansion that predicts dose-demand combinations when planar technologies would cease to be cost-effective, as well as target performance capabilities of microcarrier-based systems for the industry to be sustainable for high demand, high dose $\left(10^{9}\right.$ cells/dose) scenarios ${ }^{3}$. Technology S-curves are used to describe the development of new technologies in several industries by depicting the introduction, adoption, and maturation of the new technology ${ }^{20}$. An S-curve can be used to visualize the performance trajectory of various cell expansion technology in terms of billion cells achieved per lot against R\&D effort. Published S-curve analyses ${ }^{3}$ highlight that each progressive technology covers approximately ten fold greater performance (billion cells per lot) before being replaced by a newer technology.

\section{Storage}

Liquid nitrogen storage will be required for the majority of products in development (identified by 55\% of ISCT COG survey respondents), with cold chain distribution being an integral part of cell therapy delivery (52\% of products shipped frozen). The majority of the respondents indicated anticipated storage time requirements of less than 2 years.

The cold chain for cell therapy begins as early as tissue acquisition, storage prior and after processing, and transport and handling upon receipt to end users. A wide range of biopreservation solutions, methods and storage options, are available for users to choose based on their specific requirements ${ }^{21}$. Factors influencing the associated cost include storage time, cell bank size and concentration, temperature, and stability (Table 7).

A balance between storage time, cell bank size (i.e., lot size), clinical pre-treatment preparation, and stability must be established in order to reduce the cost and minimize the impact on cell 
functionality. Extended storage time can incur additional running costs and may raise uncertainty regarding cell stability. Lower temperatures (below $-150^{\circ} \mathrm{C}$ ) can improve stability but may be more costly. Several reviews addressing the technical aspects, such as selection of cryopreservative, cooling protocols, storage container system, temperature, period, and the effect on cell functionalities are listed in Table S1. Development of new technologies for cell preservation at ambient temperatures has emerged as a potential area technology innovation (for example, the Prestige Lyotechnology system from Osiris Therapeutics).

\section{Cost Structure Illustration}

Examining the cost structure of a cell therapy product illustrates the systematic cost components and can highlight opportunities to minimize costs through early process development planning. Figure 4 presents an example of a manually implemented protocol completed in Grade B suites, optimized as far as possible to minimize cost. This example is an anonymized cell therapy process derived from analysis of three autologous therapies. This data aligns with the COG survey results where respondents highlighted labor costs around 30\% of the total product cost.

By applying automated processing within functionally closed disposables many commercial and quality attributes of the manufacturing process are improved while also dramatically reducing the dependence on skilled labor (Fig. 4). Of particular interest is the change in cost structure, where the systematic facility and labor costs are replaced with disposable and process specific capital costs that are responsive to the economies of scale, as previously mentioned. In this example, automation led to more than 30\% savings in COG. While automation can significantly reduce COG, indirect costs associated with developing automation strategies must be considered. 


\section{Conclusion}

A strong cell therapy business model cannot be realized without taking into consideration every relevant aspect of a product lifecycle and how it can influence product cost (Fig. 5). Through strategic process design, one can influence multiple costs: capital (i.e. production facility and equipment); supply chain (consumables, cold chain); compliance (GMP production area costs); regulatory (strategic selection of QA/QC testing, automation where justified); manufacturing; quality deviations; and licensing. Success is not only built on therapeutic efficacy but also on well-defined strategies for pricing, reimbursement, and commercialization. Regulatory approval and marketing licenses are not the ultimate key to commercial success, as healthcare and reimbursement agencies are increasingly looking for cost-effective solutions. Understanding and planning the economic aspects of a new cellular therapeutic from the early phases of development will enable a viable lifecycle. The gross profit margin between the selling price of the product and all its associated costs is the only source of revenue to pay for all costs related to development, approval and sustained marketing of an innovative new therapy. While we have discussed only COG related concerns here, other important costs warrant future discussion (as outlined in Fig. 5).

It is critical to align the initial process to the preferred long term production methods as soon as possible in clinical development. Changes to processes place the entire clinical history at risk, since the product is defined by the production process itself. Product COG issues described in this paper are a tool for designing the clinical scale manufacturing process to ensure all costs are well analyzed and considered. The real value emerges from a seamless translation from clinical trials into successful and profitable commercial manufacture. 
Ultimately, developing rigorous understanding and modeling all costs is ideal for the theoretical cell therapy company with unlimited capital resources. In the capital-constrained environment in which most cell therapy companies operate, a trade-off must be made between allocating resources towards understanding cost drivers and allocating resources towards product, process, and business development. By implementing impact analysis during process development guided by the key cost drivers outlined above, such capital-constrained companies can prioritize studying the highest cost and highest risk aspects of their process development. Cost-conscious product development will make cell therapy products affordable and available to broad populations of patients in need.

\section{ACKNOWLEDGMENTS}

We acknowledge the contributions made by Knut Niss in the early stages of this project. YYL is supported as an NSERC Canada graduate scholar.

\section{DISCLOSURE OF INTEREST}




\section{REFERENCES}

1. Crabb NS, Andrew;. Exploring the assessment and appraisal of regenerative medicines and cell therapy products. In: Centre for Health Technology Evaluation NIfHaCEN, ed2016.

2. Abou-El-Enein M, Romhild A, Kaiser D, et al. Good Manufacturing Practices (GMP) manufacturing of advanced therapy medicinal products: a novel tailored model for optimizing performance and estimating costs. Cytotherapy. 2013;15:362-383.

3. Simaria AS, Hassan S, Varadaraju H, et al. Allogeneic cell therapy bioprocess economics and optimization: Single-use cell expansion technologies. Biotechnology and bioengineering. 2013.

4. Hassan S, Simaria AS, Varadaraju H, Gupta S, Warren K, Farid SS. Allogeneic cell therapy bioprocess economics and optimization: downstream processing decisions. Regenerative medicine. 2015;10:591-609.

5. Hassan S, Huang $H$, Warren $K$, et al. Process change evaluation framework for allogeneic cell therapies: impact on drug development and commercialization. Regenerative medicine. 2016;11:287-305.

6. Lipsitz YY, Timmins NE, Zandstra PW. Quality cell therapy manufacturing by design. Nat Biotech. 2016;34:393-400.

7. Flommersfeld S, Bakchoul T, Bein G, Wachtel A, Loechelt C, Sachs UJ. A single center comparison between three different apheresis systems for autologous and allogeneic stem cell collections. Transfusion and apheresis science : official journal of the World Apheresis Association : official journal of the European Society for Haemapheresis. 2013;49:428-433.

8. Brauninger S, Bialleck H, Thorausch K, Felt T, Seifried E, Bonig H. Allogeneic donor peripheral blood "stem cell" apheresis: prospective comparison of two apheresis systems. Transfusion. 2012;52:1137-1145.

9. Moog R, Muller N. Technical aspects and performance in collecting peripheral blood progenitor cells. Annals of hematology. 1998;77:143-147.

10. Remberger M, Ringden 0 , Mattsson J. Bone marrow aspiration technique has deteriorated in recent years. Bone Marrow Transplant. 2015;50:1007-1009.

11. Dzieciatkowska M, D'Alessandro A, Burke TA, et al. Proteomics of apheresis platelet supernatants during routine storage: Gender-related differences. J Proteomics. 2015;112:190-209.

12. Panch SR, Yau YY, Fitzhugh CD, Hsieh MM, Tisdale JF, Leitman SF. Hematopoietic progenitor cell mobilization is more robust in healthy African American compared to Caucasian donors and is not affected by the presence of sickle cell trait. Transfusion. 2016;56:1058-1065.

13. Baimukanova G, Miyazawa $B$, Potter DR, et al. Platelets regulate vascular endothelial stability: assessing the storage lesion and donor variability of apheresis platelets. Transfusion. 2016;56:13532.

14. Mendicino M, Bailey AM, Wonnacott K, Puri RK, Bauer SR. MSC-based product characterization for clinical trials: an FDA perspective. Cell Stem Cell. 2014;14:141145. 
15. Hourd P, Ginty P, Chandra A, Williams DJ. Manufacturing models permitting roll out/scale out of clinically led autologous cell therapies: regulatory and scientific challenges for comparability. Cytotherapy. 2014;16:1033-1047.

16. Carpenter MK, Couture LA. Regulatory considerations for the development of autologous induced pluripotent stem cell therapies. Regenerative medicine. 2010;5:569-579.

17. Food and Drug Administration. Minimal Manipulation of Human Cells, Tissues, and Cellular and Tissue-Based Products: Draft Guidance. In: (CBER); CfBEaR, (CDRH); CfDaRH, (OCP); OoCPitOotC, eds2014.

18. Kirouac DC, Zandstra PW. The Systematic Production of Cells for Cell Therapies. Cell stem cell. 2008;3:369-381.

19. Rowley J, Abraham E, Campbell A, Brandwein H, Oh S. Meeting lot-size challenges of manufacturing adherent cells for therapy. BioProcess International. 2012;10:1622.

20. Schilling MA, Esmundo M. Technology S-curves in renewable energy alternatives: Analysis and implications for industry and government. Energy Policy. 2009;37:1767-1781.

21. Stacey GN, Masters JR. Cryopreservation and banking of mammalian cell lines. Nat Protoc. 2008;3:1981-1989.

22. Ledford H. Immune cells boost cancer survival from months to years. Nature. 2014;516:156.

23. Palmer E. Novartis, others face higher manufacturing costs with CAR-T cell treatments. FiercePharma. 2015.

24. Plumridge H. New Costly Cancer Treatments Face Hurdles Getting to Patients. Wall Street Journal2014.

25. Ward A. Race to control costs of cancer therapy revolution. Financial Times2015.

26. Brandes R. Aseptic Processing: Qualification of personnel. Maas and Peithner GMP Publishing. 2012;12.

27. Food and Drug Administration. Current Good Manufacturing Practice for Finished Pharmaceuticals. In: Services; DoHaH, ed2016.

28. Ginis I, Grinblat B, Shirvan MH. Evaluation of bone marrow-derived mesenchymal stem cells after cryopreservation and hypothermic storage in clinically safe medium. Tissue Eng Part C Methods. 2012;18:453-463.

29. Davies OG, Smith AJ, Cooper PR, Shelton RM, Scheven BA. The effects of cryopreservation on cells isolated from adipose, bone marrow and dental pulp tissues. Cryobiology. 2014;69:342-347.

30. Morris C, de Wreede L, Scholten M, et al. Should the standard dimethyl sulfoxide concentration be reduced? Results of a European Group for Blood and Marrow Transplantation prospective noninterventional study on usage and side effects of dimethyl sulfoxide. Transfusion. 2014;54:2514-2522.

31. Al-Saqi SH, Saliem M, Quezada HC, et al. Defined serum- and xeno-free cryopreservation of mesenchymal stem cells. Cell Tissue Bank. 2014.

32. Hanley PJ, Mei Z, da Graca Cabreira-Hansen M, et al. Manufacturing mesenchymal stromal cells for phase I clinical trials. Cytotherapy. 2013;15:416-422.

33. Badowski M, Muise A, Harris DT. Mixed effects of long-term frozen storage on cord tissue stem cells. Cytotherapy. 2014;16:1313-1321. 
34. Bissoyi A, Pramanik K. Role of the apoptosis pathway in cryopreservation-induced cell death in mesenchymal stem cells derived from umbilical cord blood. Biopreservation and biobanking. 2014;12:246-254.

35. Shu Z, Gao D, Pu LL. Update on cryopreservation of adipose tissue and adiposederived stem cells. Clinics in plastic surgery. 2015;42:209-218.

36. Marquez-Curtis LA, Janowska-Wieczorek A, McGann LE, Elliott JA. Mesenchymal stromal cells derived from various tissues: Biological, clinical and cryopreservation aspects. Cryobiology. 2015;71:181-197.

37. Li Y, Ma T. Bioprocessing of Cryopreservation for Large-Scale Banking of Human Pluripotent Stem Cells. BioResearch open access. 2012;1:205-214.

38. Martin-Ibanez R, Stromberg AM, Hovatta O, Canals JM. Cryopreservation of dissociated human embryonic stem cells in the presence of ROCK inhibitor. Current protocols in stem cell biology. 2009; Chapter 1:Unit 1C.8.

39. Robinson NJ, Picken A, Coopman K. Low temperature cell pausing: an alternative short-term preservation method for use in cell therapies including stem cell applications. Biotechnology letters. 2014;36:201-209.

40. Hunt CJ. Cryopreservation of Human Stem Cells for Clinical Application: A Review. Transfusion Medicine and Hemotherapy. 2011;38:107-123.

41. Woods EJ, Thirumala S. Packaging Considerations for Biopreservation. Transfusion medicine and hemotherapy : offizielles Organ der Deutschen Gesellschaft fur Transfusionsmedizin und Immunhamatologie. 2011;38:149-156.

42. Inamdar MS, Healy L, Sinha A, Stacey G. Global solutions to the challenges of setting up and managing a stem cell laboratory. Stem cell reviews. 2012;8:830-843.

43. Vaught J, Lockhart NC. The evolution of biobanking best practices. Clinica chimica acta; international journal of clinical chemistry. 2012;413:1569-1575.

44. Sirchia G, Rebulla P, Tibaldi S, Lecchi L. Cost of umbilical cord blood units released for transplantation. Transfusion. 1999;39:645-650. 


\section{Figure Legends}

Figure 1 - Sales price of autologous and allogeneic cell therapies. Expected sales prices from the COG survey in 2013 are compared with published and anticipated costs for therapies approved or in trials. Prices for Glybera, Strimvelis, Prochymal, and Provenge are based on published prices from each respective company. Analyst reports of expected CAR-T prices range from $\$ 300000-5000000^{22-25}$ but not confirmed by companies developing these therapies.

Figure 2 - Allogeneic vs. autologous manufacturing models. In allogeneic therapies, a single sample is saved in a master cell bank from which a working cell bank is used for manufacturing. These therapies are then distributed to large patient populations. In autologous therapies, each single patient sample is manufactured into a product which is used to treat a single patient.

Figure 3 - Needle-to-Needle Cost Center Roadmap. COG survey respondents indicated the expected cost of each stage of the production process, identifying key cost drivers. Each stage and associated cost drivers can be aligned with a guiding cost measure and a stage of clinical development. $(\mathrm{R}=$ range of responses, $\mathrm{M}=$ mean response, $\mathrm{NI}=$ not included in survey questions)

Figure 4 - COG reduction through automation. This anonymized case study of 3 autologous processes indicate a significant saving from process automation using closed consumables of $>30 \%$.

Figure 5 - Costs related to cellular therapy business model. Many costs can be influenced through careful process design. These influences can be realized at the time the application for a new drug is being written, highlighting the importance of commercial strategy (in addition to therapeutic strategy) when investing in a cell therapy product. Consideration of COG as discussed in this paper (see terms in Bold) are an important component in identifying and managing the cost of manufacturing. Other costs not discussed here must also be taken into consideration when identifying the overall cost of bringing a cell therapy to market.

Table 1 - Cell therapy manufacturing processes steps that will be considered in this document and relevant cost considerations that will be discussed.

Table 2 - Considerations in tissue procurement for allogeneic and autologous therapies

Table 3 - Considerations in material costs in manufacturing

Table 4 - Considerations for centralized or multi-center facility approach

Table 5 - Labor considerations in clean room operations

Table 6 - Considerations for cell expansion technology selection

Table 7 - Considerations for cryopreservation of cell therapies 
Figure S1: Overview of COG survey respondents by role, geographic location, and industry sector. For more information on survey results, see:

http://c.ymcdn.com/sites/www.celltherapysociety.org/resource/resmgr/CommunityRe sources/ISCT COGs Survey Results and.pdf

Supplement Table 1 - Selected reviews on the consideration in storage of human stem cells for cell therapy. The reviews from biobanking can provide the guideline for cost of storage. Commercial courier delivery services (e.g., FedEx, World Courier, and DHL) can provide helpful information and the necessary requirements for the transportation of cells at low temperature 


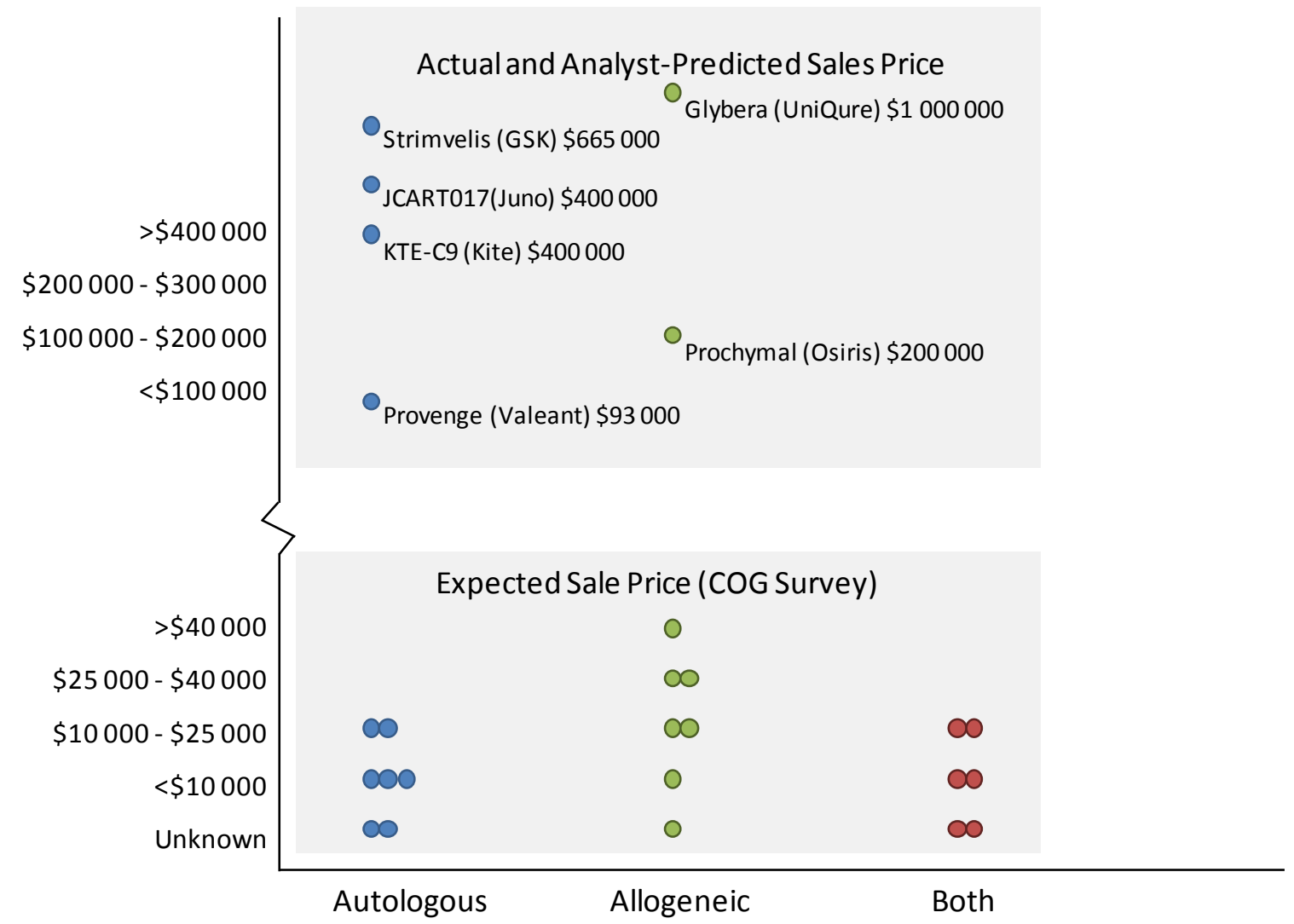

Figure 1

Autologous

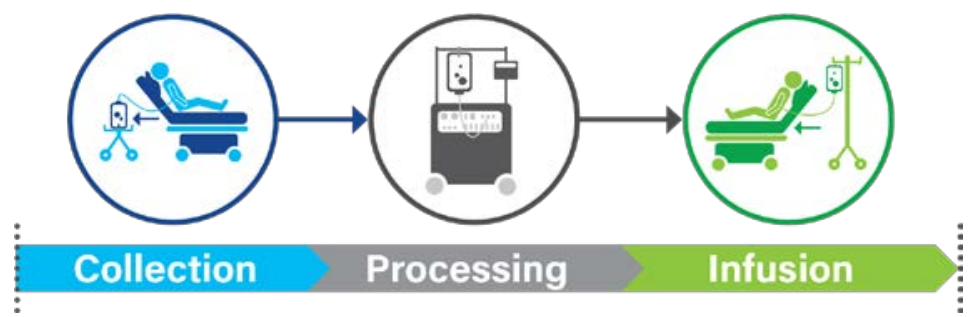

Allogeneic

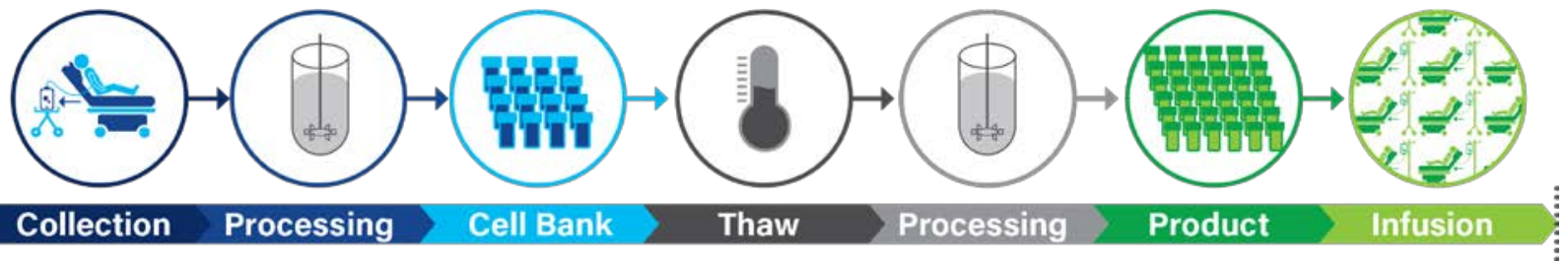

Figure 2 


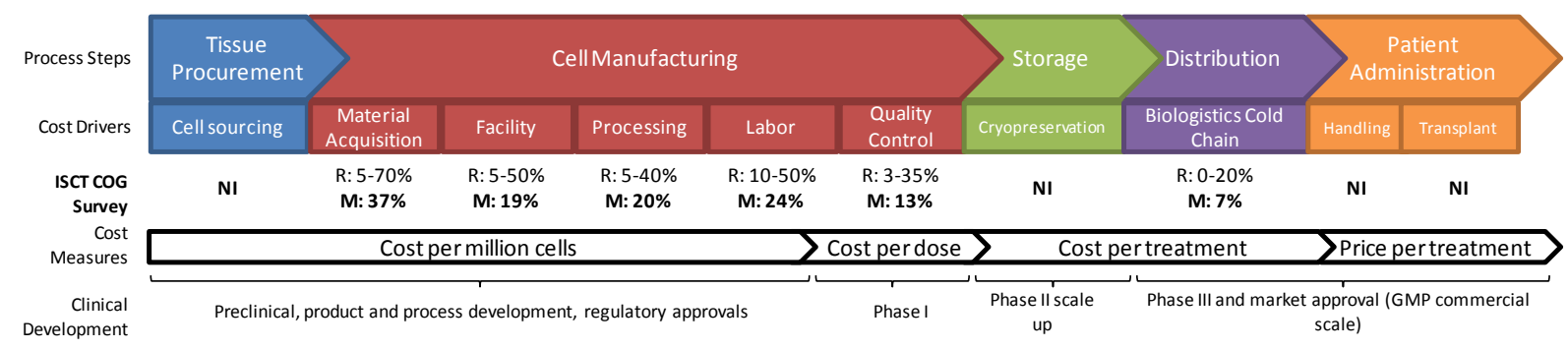

Figure 3

\begin{tabular}{|c|c|c|c|}
\hline & 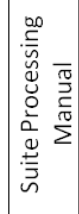 & 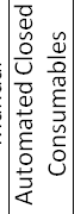 & 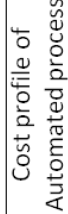 \\
\hline $\begin{array}{c}\text { Facilities } \\
\text { Amortized }\end{array}$ & $15 \%$ & $3 \%$ & \\
\hline $\begin{array}{l}\text { Equipment } \\
\text { Amortized }\end{array}$ & $3 \%$ & $3 \%$ & 4 \\
\hline Gowning & $3 \%$ & $0 \%$ & $0 \%$ \\
\hline Cleaning & $5 \%$ & $1 \%$ & $1 \%$ \\
\hline Disposables & $8 \%$ & $18 \%$ & $28 \%$ \\
\hline Reagents & $29 \%$ & $29 \%$ & $45 \%$ \\
\hline QC & $5 \%$ & $5 \%$ & $8 \%$ \\
\hline Direct Labor & $25 \%$ & $3 \%$ & $4 \%$ \\
\hline Indirect Labor & $8 \%$ & $3 \%$ & $5 \%$ \\
\hline Savings & $0 \%$ & $37 \%$ & \\
\hline Total & $100 \%$ & $100 \%$ & 110 \\
\hline
\end{tabular}

\section{Suite Processing Automated Closed Manual Consumables}
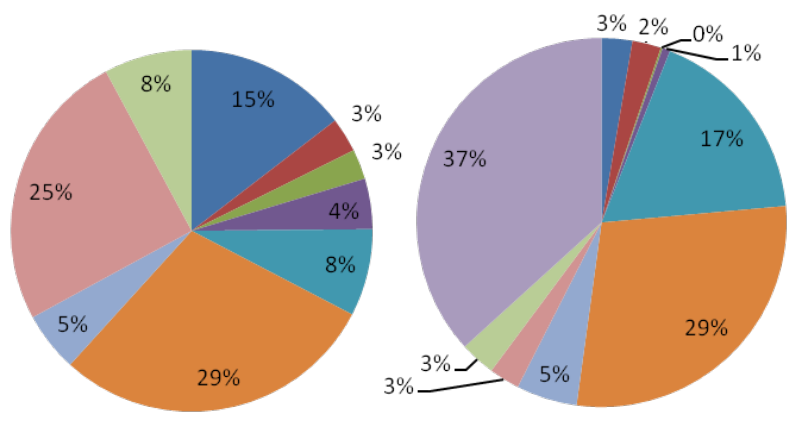

- Facilities Amortized

Equipment Amortized

Gowning

- Cleaning

Disposables

Reagents

$\square \mathrm{QC}$

Direct Labor

Indirect Labor

a Savings

Figure 4 


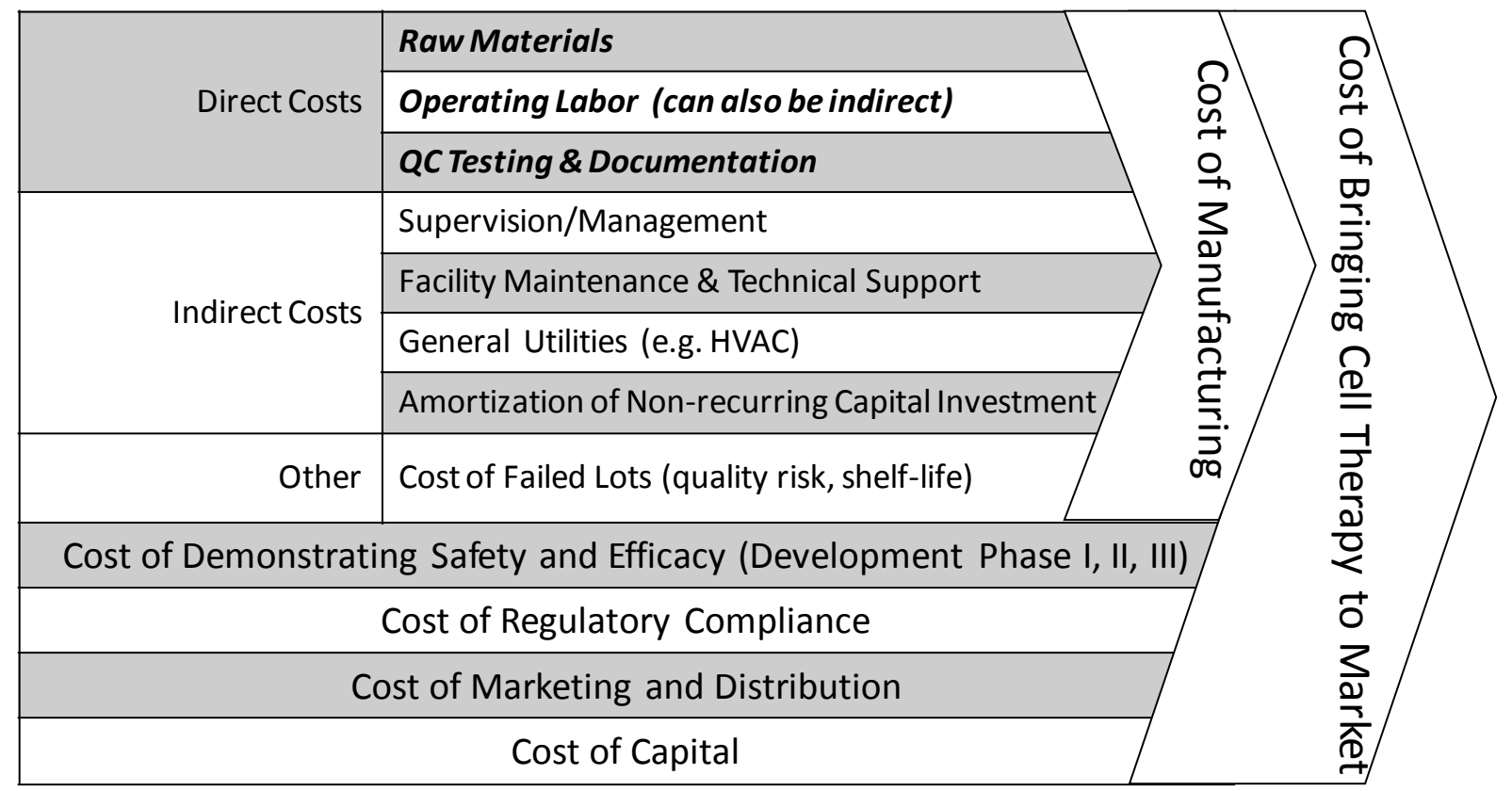

\section{Figure 5}

\begin{tabular}{|l|l|}
\hline \multicolumn{1}{|c|}{ Process Step } & \multicolumn{1}{c|}{ Relevant Cost Considerations } \\
\hline Tissue procurement & $\begin{array}{l}\text { Screening, clinical acquisition, scheduling, variability in quality, transport, } \\
\text { regulatory compliance }\end{array}$ \\
\hline Material Acquisition & $\begin{array}{l}\text { Medium, supplements, cell cultures, commercial demand, consistency, } \\
\text { bioequivalence }\end{array}$ \\
\hline Facility Operation & $\begin{array}{l}\text { Forecast demand, production scale required, outsourcing or building, central or } \\
\text { multi-centre, clean room environment for GMP manufacturing, comparability } \\
\text { between sites }\end{array}$ \\
\hline Production & $\begin{array}{l}\text { Personnel, cell culture, aseptic processing, automation, and Quality Control } \\
\text { selection }\end{array}$ \\
\hline Storage & Packaging, cryopreservation agents, storage temperature and storage time \\
\hline
\end{tabular}

\section{Table 1}

\begin{tabular}{|l|l|}
\hline \multicolumn{1}{|c|}{ Topic } & \multicolumn{1}{c|}{ Key Considerations } \\
\hline \multirow{4}{*}{$\begin{array}{l}\text { General } \\
\text { Considerations }\end{array}$} & $\begin{array}{l}\text { Ensure aseptic handling from the initial collection to the initiation of manufacturing } \\
\text { processing }\end{array}$ \\
\cline { 2 - 2 } & Efficiently schedule processing to match time of tissue arrival \\
\hline
\end{tabular}




\begin{tabular}{|l|l|}
\hline \multirow{4}{*}{ Allogeneic } & $\begin{array}{l}\text { Screen tissue / donors, adhering to regulatory agency donor and procurement guidelines of } \\
\text { all markets where the cells may be ultimately used }\end{array}$ \\
\cline { 2 - 3 } & Determine need and/or frequency of primary cell culture qualification \\
\hline \multirow{4}{*}{ Autologous } & $\begin{array}{l}\text { Establish and control consistent acquisition processes for multiple patients at multiple } \\
\text { clinics }\end{array}$ \\
\cline { 2 - 3 } & $\begin{array}{l}\text { Use GMP-compliant and sterile procurement, handling, preservation and storage of the } \\
\text { starting materials }\end{array}$ \\
\cline { 2 - 2 } & Drugs required for procurement of tissue \\
\hline
\end{tabular}

\section{Table 2}

\begin{tabular}{|l|l|}
\hline \multicolumn{1}{|c|}{ Topic } & \multicolumn{1}{c|}{ Key Considerations } \\
\hline \multirow{3}{*}{$\begin{array}{l}\text { Pissue } \\
\text { Procurement }\end{array}$} & $\begin{array}{l}\text { Secure required quantities by selecting supplements and other consumables that will be readily } \\
\text { available in large quantities to meet production scale requirements for commercial demand }\end{array}$ \\
\cline { 2 - 3 } & $\begin{array}{l}\text { Start with materials that are deemed by regulatory authorities in key target markets to be safe } \\
\text { ancillary materials to avoid any required changes in your manufacturing process downstream }\end{array}$ \\
\cline { 2 - 3 } & $\begin{array}{l}\text { Consistently use the same materials, from the same sources, to reduce the risk of variance } \\
\text { resulting from changes in materials utilized in the cells produced }\end{array}$ \\
\cline { 2 - 3 } & $\begin{array}{l}\text { When possible, replace complex, animal sourced materials from media formulations with } \\
\text { well-defined components }\end{array}$ \\
\cline { 2 - 3 } & $\begin{array}{l}\text { Create and test strategies for "bioequivalence" as part of the CMC for those reagents at risk of } \\
\text { supply disruption }\end{array}$ \\
\cline { 2 - 3 } & $\begin{array}{l}\text { Minimize the amount of consumable and disposable waste materials to manage costs and } \\
\text { minimize environmental issues }\end{array}$ \\
\cline { 2 - 3 } & $\begin{array}{l}\text { Comprehend the systematic costs driven by process decisions, (for example antibody based } \\
\text { cell selection is always likely to be a high cost) }\end{array}$ \\
\hline
\end{tabular}

\section{Table 3}

\begin{tabular}{|l|l|l|l|l|l|}
\hline \multicolumn{1}{|c|}{ Facility Design } & Product & \multicolumn{1}{|c|}{ Capacity } & \multicolumn{1}{|c|}{$\begin{array}{c}\text { Capacity } \\
\text { Increase }\end{array}$} & $\begin{array}{c}\text { Change } \\
\text { Implementation }\end{array}$ & \multicolumn{1}{|c|}{ Logistics } \\
\hline Centralized & Frozen & $\begin{array}{l}\text { Dependent on } \\
\text { market } \\
\text { demand }\end{array}$ & $\begin{array}{l}\text { Expansion of } \\
\text { existing facility } \\
\text { or conversion to } \\
\text { multi-centre }\end{array}$ & $\begin{array}{l}\text { Centralized to one } \\
\text { centre }\end{array}$ & $\begin{array}{l}\text { Potentially } \\
\text { more flexible, } \\
\text { depending on } \\
\text { existing } \\
\text { infrastructure }\end{array}$ \\
\hline Multi-centre & $\begin{array}{l}\text { Fresh } \\
\text { Frozen }\end{array}$ & $\begin{array}{l}\text { Dependent on } \\
\text { local demand }\end{array}$ & $\begin{array}{l}\text { Establishment } \\
\text { of new centres }\end{array}$ & $\begin{array}{l}\text { Complex } \\
\text { (technology } \\
\text { transfer to each } \\
\text { site, and inter-site } \\
\text { comparability) }\end{array}$ & $\begin{array}{l}\text { Dependent on } \\
\text { local } \\
\text { infrastructure }\end{array}$ \\
\hline
\end{tabular}




\section{Table 4}

\begin{tabular}{|l|l|}
\hline \multicolumn{1}{|c|}{ Topic } & \multicolumn{1}{c|}{ Key Considerations } \\
\hline Training & Qualification and regular re-validation of operator aseptic technique ${ }^{26}$ \\
\hline Staffing & $\begin{array}{l}\text { Independent protocol verification of batch record for manual protocols } \\
\text { (dedicated staff required to monitor active operator) }\end{array}$ \\
\cline { 2 - 2 } & $\begin{array}{l}\text { Reduced productive hours of personnel working in clean rooms due to } \\
\text { gowning times and restricted movement }\end{array}$ \\
\cline { 2 - 2 } & $\begin{array}{l}\text { Additional personnel required to supply and remove materials from clean } \\
\text { spaces }\end{array}$ \\
\hline
\end{tabular}

Table 5

\begin{tabular}{|l|l|}
\hline Topic & Key COG considerations \\
\hline Demand & $\begin{array}{l}\text { Where possible, design the manufacturing process to be suitable for commercial } \\
\text { demands from the start }\end{array}$ \\
\hline $\begin{array}{l}\text { Operational } \\
\text { Performance and } \\
\text { Lot Size }\end{array}$ & $\begin{array}{l}\text { Use estimates of expansion yields or harvest densities and downstream yields to } \\
\text { determine if number of expansion units per lot is practical for each technology } \\
\text { choice }\end{array}$ \\
\hline $\begin{array}{l}\text { QC and regulatory } \\
\text { compliance }\end{array}$ & $\begin{array}{l}\text { Automated or manual processing and open or closed processing are key decisions. } \\
\text { Currently, most processes involve manual handling. Automated and closed } \\
\text { processing may reduce costs and improve cell quality } \\
\text { Costs of developing process understanding to implement Quality-by-Design } \\
\text { process development }\end{array}$ \\
\hline Scalability & $\begin{array}{l}\text { Multi-layer vessels can reach production limitations at higher cell production } \\
\text { numbers. Determine by using the S-curve method }{ }^{3} \text { if the desired lot sizes over a } \\
\text { product lifecycle can be met by planar technologies or whether a switch to } \\
\text { bioreactor technologies is required }\end{array}$ \\
\hline $\begin{array}{l}\text { Process } \\
\text { development effort }\end{array}$ & $\begin{array}{l}\text { If switches in technology are planned later in the development pathway, then the } \\
\text { economic consequences of process changes need to be considered }\end{array}$ \\
\hline $\begin{array}{l}\text { Upstream v } \\
\text { downstream } \\
\text { processing costs } \\
\text { (USP:DSP) }\end{array}$ & $\begin{array}{l}\text { Consider the ratio of USP to DSP costs and potential bottlenecks to prioritize R\&D } \\
\text { efforts. Typical contributions of DSP are 10-20\% in planar processes employing } \\
\text { multi-layer vessels and 50-80\% in bioreactor-based processes }\end{array}$ \\
\hline
\end{tabular}

Table 6

\begin{tabular}{|l|l|}
\hline \multicolumn{1}{|c|}{ Topic } & \multicolumn{1}{c|}{ Key Considerations } \\
\hline Cryopreservation & $\begin{array}{l}\text { DMSO, a common cryopreservative may cause dose-related side effects }{ }^{28-30} \\
\text { Costly proprietary agents can be substituted }\end{array}{ }^{31}$. \\
\hline $\begin{array}{l}\text { Storage } \\
\text { temperature, }\end{array}$ & $\begin{array}{l}\text { Four methods are available for cryogenic temperature storage: } \\
\text { 1) Electrical mechanical freezer }\left(-130^{\circ} \mathrm{C}\right) \\
\text { a. } \quad \text { High running cost, warm temperature }\end{array}$ \\
\hline
\end{tabular}




\begin{tabular}{|c|c|}
\hline Topic & Key Considerations \\
\hline & $\begin{array}{l}\text { 2) Liquid nitrogen, liquid phase }\left(-196^{\circ} \mathrm{C}\right) \\
\text { a. Medium running cost, very steady temperature, risk of cross } \\
\text { contamination, higher user safety risks } \\
\text { 3) Liquid nitrogen, vapor phase, low efficiency }\left(>-150^{\circ} \mathrm{C}\right) \\
\text { a. Medium running cost, temperature fluctuation and no risk of cross- } \\
\text { contamination } \\
\text { 4) Liquid nitrogen, vapor phase, high efficiency }\left(-190^{\circ} \mathrm{C}\right) \\
\text { a. Low running cost, steady temperature, no risk of cross contamination } \\
\text { Additional cryopreservation equipment should be used to control cryovial transfers } \\
\text { between storage containers during transport to avoid temperature variance }\end{array}$ \\
\hline Cell concentration & $\begin{array}{l}\text { Reduced cell viability after thawing might necessitate larger or more complex-to- } \\
\text { harvest source tissue }\end{array}$ \\
\hline Storage duration & Production should closely match demand to minimize storage costs \\
\hline
\end{tabular}

Table 7

\section{Supplementary Material}

WHAT POSITION REPONDENTS HOLD

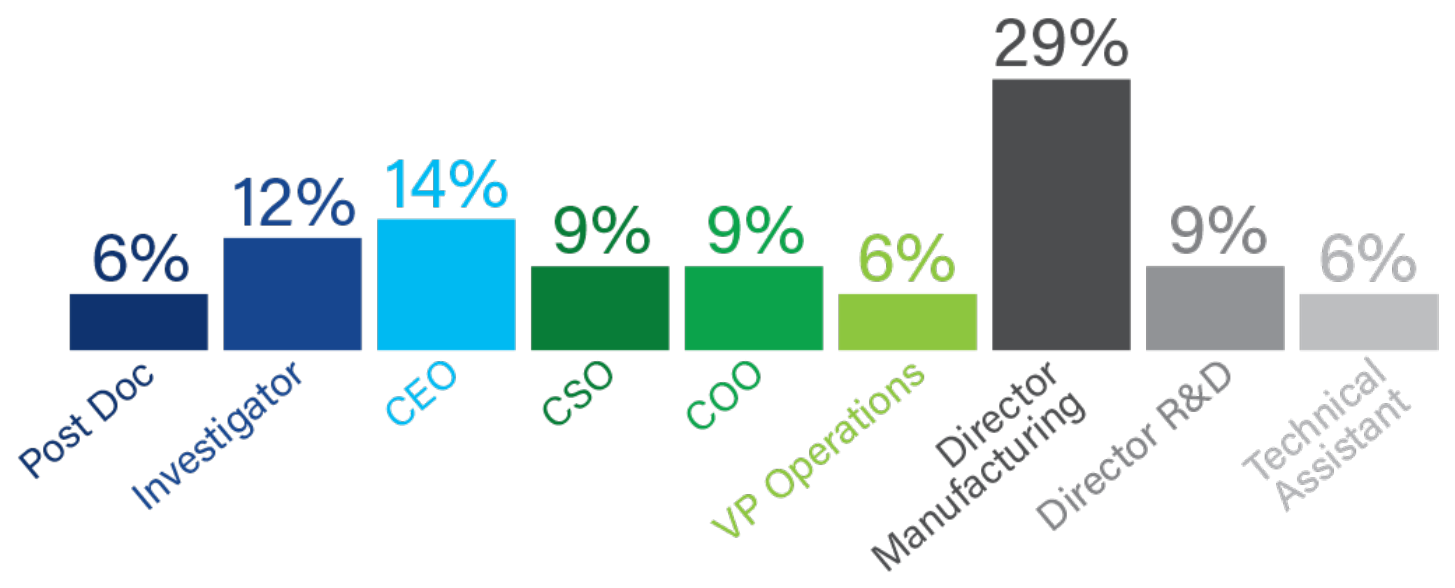



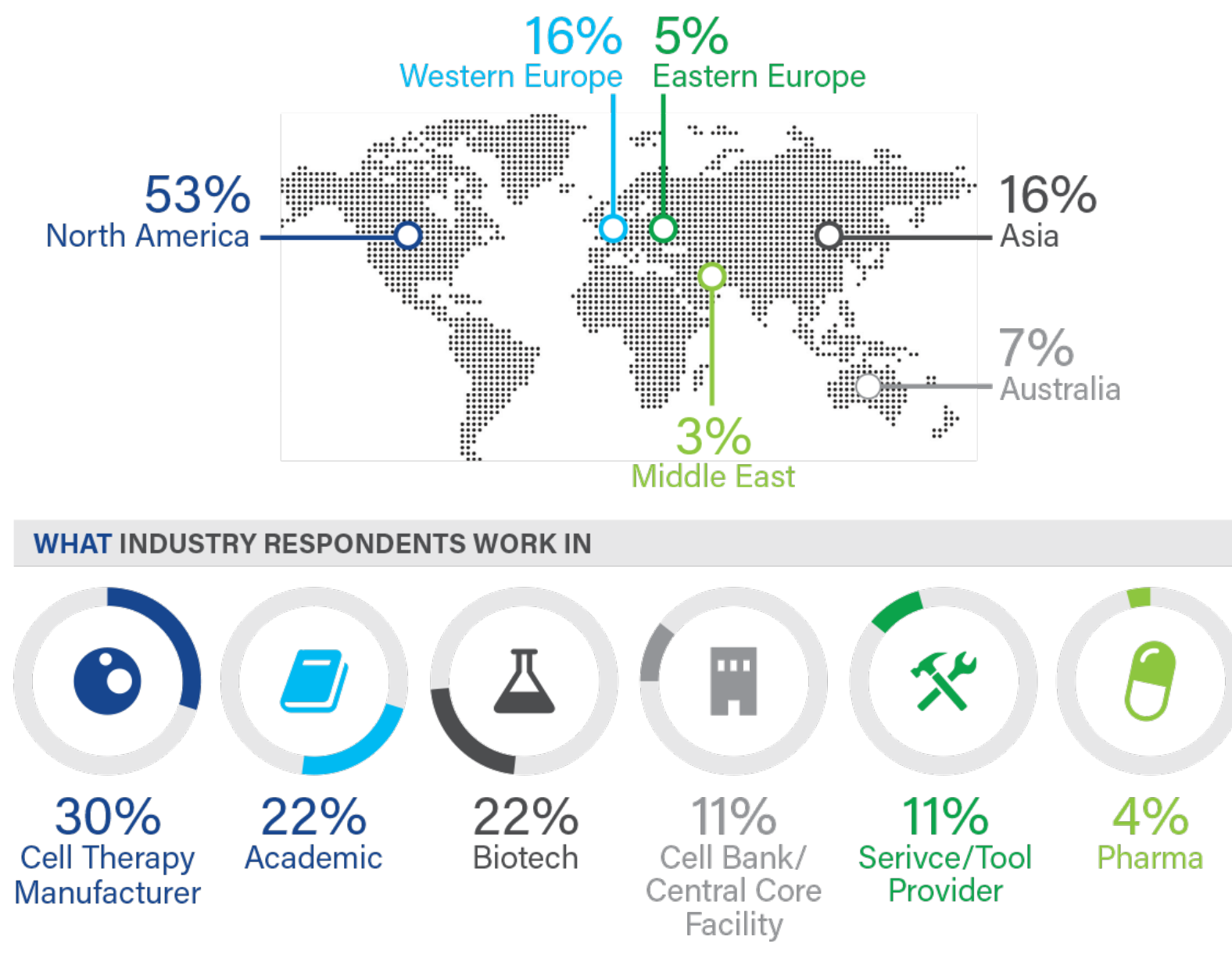

Figure S1

\section{Table S1}

\begin{tabular}{|c|c|c|}
\hline Consideration & Cell Type & Reviews \\
\hline Cryopreservation & $\begin{array}{l}\text { Adipose tissue and adipose derived stem } \\
\text { cells }\end{array}$ & Shu et al $2015^{35}$ \\
\hline Cryopreservation & Human mesenchymal stem cells & Marquez-Curtis et al $2015^{36}$ \\
\hline Cryopreservation & Human pluripotent stem cells & $\mathrm{Li}$ and Ma $2012^{37}$ \\
\hline Cryopreservation & Human pluripotent stem cells & Martín-Ibáñez et al $2012^{38}$ \\
\hline Hypothermic storage & Human mesenchymal stem cells & Robinson et al $2014^{39}$ \\
\hline
\end{tabular}




\begin{tabular}{|l|l|l|}
\hline \multicolumn{1}{|c|}{ Consideration } & \multicolumn{1}{c|}{ Cell Type } & \multicolumn{1}{c|}{ Reviews } \\
\hline & Human pluripotent stem cells & Hunt et al $2011^{40}$ \\
\hline $\begin{array}{l}\text { Cryopreservation, storage and } \\
\text { transportation }\end{array}$ & $\begin{array}{l}\text { Human mesenchymal stem cells } \\
\text { Human pluripotent stem cells } \\
\text { Haematopoietic stem cells }\end{array}$ & Woods and Thirumala $2011^{41}$ \\
\hline Packaging & Human mesenchymal stem cells & Inamdar et al 2012 \\
\hline Setting up and managing & None specific & Vaught and Lockhart $2012^{43}$ \\
\hline Biobanking practices & None specific & Sirchia et al $1999^{44}$ \\
\hline Economic and cost analysis & Umbilical cord blood & \\
\hline
\end{tabular}

